Acta Universitatis Wratislaviensis • No 4055

Literatura i Kultura Popularna XXVII, Wrocław 2021

https://doi.org/10.19195/0867-7441.27.6

\author{
Krzysztof Rybak \\ ORCID: 0000-0001-8018-2622 \\ Uniwersytet Warszawski
}

\title{
Minotaur, Morlok, bestia... Obrazy niemieckich żołnierzy w polskiej literaturze dziecięcej o Zagładzie*
}

\begin{abstract}
Słowa kluczowe: polska literatura dziecięca, potworność, Zagłada, Holokaust, II wojna światowa, wojna
\end{abstract}

Keywords: Polish children's literature, monstrosity, Shoah, Holocaust, World War II, war

Wojna jest zjawiskiem chaotycznym i niezrozumiałym, zarówno dla dzieci, jak i dorosłych: trudno pojąć jej genezę, skomplikowany przebieg i skutki. Nie inaczej jej obraz kreują autorzy utworów skierowanych do niedorosłych czytelników. Aby poradzić sobie z wydarzeniami, których uczestnikami dziecięcy bohaterowie stali się mimowolnie, protagoniści odwołują się do pokładów wyobraźni, która pomaga $\mathrm{w}$ oswojeniu otaczającego ich świata. Z jednej strony pozwala ona zrekonstruować utraconą dziecięcą arkadię, z drugiej przekształca obce twory w znane dziecięcej imaginacji obrazy, w tym obrazy potworności ${ }^{1}$.

Niniejszy tekst jest poświęcony właśnie tego rodzaju upiornym przedstawieniom niemieckich żołnierzy, zawartym w wybranych polskich książkach dla nie-

* Praca naukowa finansowana ze środków budżetowych na naukę w latach 2016-2020 jako projekt badawczy w ramach programu „Diamentowy Grant” Ministerstwa Nauki i Szkolnictwa Wyższego. Projekt nosi tytuł „Oczami dziecka. Zagłada w polskiej literaturze dziecięcej i młodzieżowej po roku 1989” i jest realizowany na Wydziale „Artes Liberales” Uniwersytetu Warszawskiego pod opieką prof. dr. hab. Grzegorza Leszczyńskiego (Wydział Polonistyki UW). Więcej informacji na stronie projektu zob. K. Rybak, Oczami dziecka, https://bit.ly/2VZ0MEf (dostęp: 27.12.2019).

1 Tego rodzaju oswajanie świata można odnaleźć również w kulturze ludowej; zob. V. Wróblewska, ,Od potworów do znaków pustych”. Ludowe demony w polskiej literaturze dla dzieci, Toruń 2014, s. 7. 
dorosłych o Zagładzie Żydów ${ }^{2}$. W pierwszej kolejności omówię przykłady takich kreacji antagonistów, nierzadko pozbawionych wszelkich cech ludzkich, ukazując paralele łączące ich obrazy z fragmentami literatury dokumentu osobistego powstałymi w czasach II wojny światowej. Następnie rozważę zebrany materiał w kontekście tezy o „banalności zła” postawionej przez Hannah Arendt w ramach jej spostrzeżeń dotyczących natury niemieckich zbrodniarzy wojennych ${ }^{3}$.

Należy na wstępie wspomnieć, że potwornieniu ulegają nie tylko postaci antagonistów, ale też pojęcia abstrakcyjne i maszyneria wojskowa. Dzieje się tak choćby w, co prawda niemówiących o Zagładzie ${ }^{4}$, autobiograficznych opowiadaniach Joanny Papuzińskiej, których bohaterka i narratorka Asiunia, słysząc niejasne dla pięcioletniej dziewczynki słowo, widzi potwora: „Front tędy przeszedł mówili bracia, a ja myślałam [...], że ten front to taki zły olbrzym z bajki, coś jakby troll [...], który szedł i ogromnymi nożyskami wszystko deptał i łamał"5. Również na ilustracji Macieja Szymanowicza potwór przybiera postać szarego, włochatego giganta $z$ długim ogonem i rogami, łamiącego drzewa i niszczącego domy $^{6}$, powraca również w przedsennych wyobrażeniach Asiuni, chowającej się przed nim pod kołdrą ${ }^{7}$.

Abstrakcyjny „front” to nie jedyne zjawisko, które nabiera potwornych cech: „Niemcy byli silniejsi, mieli dużo więcej żołnierzy, karabinów, armat i wszystkiego niż my. I mieli swoje straszne czołgi, żelazne potwory, które strzelały do ludzi na ulicach"». Choć w tym wypadku ,żelaznymi potworami” określane są czołgi,

2 Poruszane w tekście zjawiska były sygnalizowane już wcześniej; zob. np. K. Rybak, Dzieciństwo w labiryncie getta. Recepcja mitu labiryntu w polskiej literaturze dziecięcej o Zagładzie, Warszawa 2019, s. 87-97. O figurze odczłowieczonego nazisty w literaturze anglojęzycznej zob. m.in. L. Kokkola, Representing the Holocaust in Children's Literature, London 2003, s. 132-137. O podobnym zjawisku mówiła Agnieszka Karczewska w referacie Obraz Niemców w dziecięcej literaturze o Zagładzie (od roku 2007) wygłoszonym w trakcie konferencji „Przestrzenie literatury dla młodego czytelnika. Perspektywa niemiecka i polska" (Oświęcim, 19-20 października 2017). Niestety nie miałem okazji wysłuchać jej wystąpienia, a autorka nie opublikowała do tej pory swoich rozważań.

${ }^{3}$ Zob. H. Arendt, Eichmann w Jerozolimie. Rzecz o banalności zła, przeł. A. Szostkiewicz, Kraków 2010.

4 Twórcy książek dla dzieci o wojnie — zarówno autorzy, jak i ilustratorzy — bardzo często w swoich publikacjach przywołują figury potwora; zob. m.in. P. Beręsewicz, Czy wojna jest dla dziewczyn?, Łódź 2010; D. Cali, S. Bloch, Wróg, przeł. K. Skalska, Poznań 2014; J. Dukaj, Wroniec, Kraków 2009. Podobnie przedstawiani się antagoniści w utworach o uchodźcach; zob. K. Rybak, Żyd i uchodźca. Znaczace powinowactwa narracyjne w polskiej literaturze dziecięcej ostatniej dekady, „Czy/tam/czy/tu. Literatura dziecięca i jej konteksty” 2017, nr 2, s. 44-62.

5 J. Papuzińska, Asiunia, Łódź 2011, s. 28.

6 Zob. ibidem.

${ }^{7}$, ,...] kiedy byłam już trochę większa, zły front poszedł sobie gdzieś daleko, a może nawet całkiem przepadł. Zostały po nim tylko sterty gruzu w naszym mieście [...]. Niestety, ten zły olbrzym czasami odwiedzał nas w snach i wciąż się go baliśmy" - J. Papuzińska, Krasnale i olbrzymy, Łódź 2015, s. 14-15.

8 J. Papuzińska, Mój tato szczęściarz, Łódź 2014, s. 16. 
a więc środki transportu i destrukcji będące w posiadaniu Niemców, autorzy często nakładają maski potworów samym żołnierzom. Wykreowani przez dorosłych pisarzy dziecięcy bohaterowie wykorzystują własną wyobraźnię i tworzą fantastyczne obrazy - często oddawane przez ilustratorów — by oswoić drastyczne zachowanie antagonistów.

Trzeba zaznaczyć, że potworność przeciwników zostaje podkreślona w wielu dostępnych w Polsce utworach, w każdym przypadku jest ona jednak realizowana w sposób szczególny; ich krótkie omówienie ułatwi podział figur na trzy grupy. Podział postaci związany jest z cechami zewnętrznymi i zakłada (1) zachowanie naturalnego wyglądu człowieka lub przekroczenie fizycznej normy, tworząc istoty zdeformowane, będące (2) całkowicie efektem imaginacji autora lub (3) nawiązaniami do innych tekstów kultury.

W pierwszej grupie znajdują się z pozoru zwykli ludzie, których potworność objawia się w wypowiedziach bohaterów lub narratora. Można wśród nich umieścić Kotkę Brygidy Joanny Rudniańskiej - Stańcia, gosposia głównej bohaterki, mówi bowiem o niemieckich żołnierzach „one", , co rozumiem nie tylko jako wykorzystanie niskiego rejestru językowego, ale też zastosowanie uprzedmiotowiającego rodzaju nijakiego. Z kolei w Listach w butelce Anny Czerwińskiej-Rydel występują „,bestie w niemieckich mundurach”10, a w książce o znaczącym tytule Ta potworna wojna Grażyny Bąkiewicz potworem nazywany jest Adolf Hitler ${ }^{11}$. Wskazane strategie odczłowieczenia zakładają wydobycie na wierzch monstrualnych cech, zachowując przy tym realizm przedstawienia — również na poziomie ilustracji jak w przypadku książek Czerwińskiej-Rydel i Bąkiewicz — i nie angażując wyobraźni młodych bohaterów.

Inaczej jest $\mathrm{w}$ kolejnych wyłonionych grupach postaci. W drugiej zawierają się realizacje potworności fizycznej, objawiającej się odstępstwem od normy, niebędące jednak odwołaniami do znanych z kultury stworzeń. Taką postać można odnaleźć w Rutce Joanny Fabickiej — w negatywnym świetle przedstawiony zostaje przewodniczący Rady Żydowskiej łódzkiego getta Chaim Morechaj Rumkowski, którego ostrej krytyki i utożsamienia z nazistami można się doszukać choćby w Dzienniku Dawida Sierakowiaka ${ }^{12}$. Rumkowski zostaje przez Fabicką ukazany jako latający upiór pożerający motyle, zwany „Białym Panem”"13, postać wymyka się jednak jednoznacznym interpretacjom. Anna Pekaniec twierdzi enigmatycznie, że pożeranie motyli w Rutce to „metafora niezwykle czytelna dla dorosłych

9 Zob. J. Rudniańska, Kotka Brygidy, Lasek 2007, s. 35, 58, 72.

10 A. Czerwińska-Rydel, Listy w butelce. Opowieść o Irenie Sendlerowej, Łódź 2018, s. 73.

11 Zob. G. Bąkiewicz, Ale historia... Ta potworna wojna, Warszawa 2019, s. 54.

$12 \mathrm{~W}$ pisanym w łódzkim getcie dzienniku kilkunastoletni Dawid Sierakowiak stwierdził, że „lepszego od Rumkowskiego nie mogli sobie Niemcy znaleźć”, a jedną z jego przemów określił „prawdziwie »führerowską«" — idem, Dziennik, oprac. E. Wiatr, A. Sitarek, Warszawa 2016, s. $179,188$.

13 Zob. J. Fabicka, Rutka, Warszawa 2016, s. 105, 142-144. 
i stanowiąca punkt wyjścia do dyskusji z młodymi czytelnikami”"14. Katarzyna Slany widzi w tej kreacji „mocno zarysowaną postać”, podlegającą — jak inne elementy pejzażu getta — ,interpretacji tylko przez dojrzałego odbiorcę, wyposażonego w ogólną wiedzę o Holokauście, jednak nawet wówczas jest to interpretacja intuicyjna" ${ }^{15}$. Maciej Skowera twierdzi natomiast, że Fabicka inspirowała się postacią greckiego boga Kronosa, pożerającego własne dzieci ${ }^{16}$. Tak nieoczywiste konotacje postaci Rumkowskiego mogą wiązać się z jego statusem - z jednej strony był to bowiem najważniejszy Żyd łódzkiego getta, podobnie jak jego pobratymcy skazany na Zagładę, choć próbujący odsunąć w czasie swoją śmierć, wykonując polecenia Niemców; z drugiej został upamiętniony — zarówno w literaturze dokumentu osobistego (Sierakowiak), jak i beletrystyce (Kupiec tódzki Adolfa Rudnickiego i Fabryka muchołapek Andrzeja Barta ${ }^{17}$ ) — jako postać negatywna. Podobnie niejednoznaczną genezę mają odczłowieczeni żołnierze, których często na poziomie ilustracji reprezentują czarne oficerki. Katarzyna Wądolny-Tatar wskazuje, że te elementy ilustracji używane są w kategorii synekdochy ${ }^{18}$, sam zaś traktuję je jako wyraz potworności, zakładającej gigantyczne rozmiary antagonistów - takie obrazy można odnaleźć w Jest taka historia Beaty Ostrowickiej z ilustracjami Joli Richter-Magnuszewskiej czy Bruno. Chłopiec, który nauczyt się latać (Bruno. Il bambino che imparò a volare, 2012; wyd. pol. 2016) Nadii Terranovy i Ofry Amit ${ }^{19}$.

Ostatnią grupę tworzą modyfikacje figur znanych z tekstów kultury, takich jak mity i literatura fantastyczna. Mitologiczne harpie przypominają niemieccy żołnierze przedstawieni przez Joannę Concejo w książce obrazkowej Dym (Fume,

14 A. Pekaniec, Dwie opowieści o wojnie, Holokauście i nie tylko. Kotka Brygidy Joanny Rudniańskiej $i$ Rutka Joanny Fabickiej, „Czy/tam/czy/tu. Literatura dziecięca i jej konteksty” 2017, nr 1, s. 18. Ten motyw nie jest obcy w mówieniu o Zagładzie — o krematoriach w Oświęcimiu pisze izraelski historyk Otto Dov Kulka: „Okrążałem je, jak ćma okrąża płomień, wiedząc, że wpadnięcie weń jest nieuniknione, a mimo to ciągle krążyłem wokół, chcąc, nie chcąc — nie zależało to ode mnie - podczas gdy wszyscy moi znajomi, motyle, nie wszyscy, ale prawie wszyscy trafili tam i stamtąd nie wyszli” - idem, Pejzaże metropolii śmierci. Rozmyślania o pamięci i wyobraźni, przeł. M. Szczubiałka, Wołowiec 2014, s. 27.

15 K. Slany, Rutka Joanny Fabickiej jako przykład postpamięciowej literatury dla dzieci, „Maska” 2017, nr 35, s. 87.

16 Zob. M. Skowera, Rutka, [hasło w:] Our Mythical Childhood Survey, https://bit.ly/3ioCNFR (dostęp: 27.12.2019).

17 Zob. A. Rudnicki, Kupiec tódzki, [w:] idem, Kupiec tódzki. Niebieskie kartki, Warszawa 1963, s. 8-51. W powieści Barta Rumkowski nazywany jest między innymi „Chaimem Groźnym” i ,potworem” - idem, Fabryka mucholapek, Warszawa 2008, s. 60, 160.

18 Zob. K. Wądolny-Tatar, Synekdocha jako trop wizualny w ksiązkowych ilustracjach dla dzieci (na przyktadzie wybranych narracji słowa i obrazu o drugiej wojnie światowej), [w:] Literatura i inne sztuki w przestrzeni edukacyjnej dziecka, red. A. Ungeheuer-Gołąb, U. Kopeć, Rzeszów 2016, s. 169-170.

19 Zob. B. Ostrowicka, Jest taka historia. Opowieść o Januszu Korczaku, Łódź 2012, s. 5455; N. Terranova, O. Amit, Bruno. Chłopiec, który nauczyt się latać, przeł. J. Wajs, Wrocław 2016 [b.n.s.]. 
2008; wyd. pol. 2011), ukazani jako latające postaci z ostrymi dziobami i czarnymi, gęsto opierzonymi skrzydłami zamiast rąk ${ }^{20}$. Za tą interpretacją ilustracji Concejo przemawia nie tylko ich wygląd (harpie były najczęściej przedstawiane pod postacią uskrzydlonych kobiet albo ptaków z ludzką głową), ale również natura tych stworzeń - porywały one bowiem dzieci i dusze ${ }^{21}$. Natomiast w Bezsenności Jutki Doroty Combrzyńskiej-Nogali postać mitologicznego Minotaura przyjmują między innymi niemieccy żołnierze ,grasujący” w łódzkim getcie. W czasie ucieczki przed jednym z nich tytułowa bohaterka wraz z przyjaciółmi biegnie dobrze znanymi uliczkami i przejściami „labiryntu bałuckich domów, szop i komórek"22. Literacki opis uzupełnia ilustracja Joanny Rusinek, na której widać uciekające dzieci, a za nimi cień goniącego je mężczyzny. Potworność Niemca sugeruje nie tylko ciemna sylwetka, lecz także ręce ułożone w kształt przypominający rogi Minotaura. Ponadto w oczach dziewczynki mitologicznym potworem staje się Rumkowski - 5 września 1942 roku rozpoczęła się bowiem „Wielka Szpera", w ramach której okupant chciał się pozbyć osób niezdolnych do pracy:

Pewnego dnia najważniejszy człowiek w getcie, [...] Rumkowski, którego wszyscy się bali, ale go słuchali, powiedział, że muszą oddać dzieci i starych ludzi. Jutka wiedziała, że ten potwór Minotaur chce ich pożreć. [...] wiedziała, że potwór — człowiek z głową byka chce pożreć dzieci i ich babcie, i dziadków ${ }^{23}$.

Rumkowski w oczach Jutki staje się ludożerczym, potwornym Minotaurem i mimo że jest Żydem, to w Bezsenności Jutki — podobnie jak w Rutce Fabickiej — zostaje odczłowieczony i wpisany w krąg antagonistów, skutecznie realizuje bowiem politykę nazistowską.

W Arce czasu Marcina Szczygielskiego świat getta i niemieckiej okupacji w Warszawie widzimy oczami Rafała, miłośnika książek, szczególnie fantastyki. Chłopiec czyta między innymi Wehikut czasu (The Time Machine, 1895; wyd. pol. 1899) Herberta George'a Wellsa, który wpłynął na niego tak mocno, że zaczął postrzegać otaczający go świat przez pryzmat powieściowych wydarzeń. Z perspektywy chłopca niemieccy żołnierze są w związku z tym potwornymi, groźnymi i szpetnymi „Morlokami”, a Żydzi „Elojami” — białymi, czystymi istotami terroryzowanymi przez tych pierwszych ${ }^{24}$. Siła wyobraźni i wrażliwość czytelnicza

20 A. Fortes, J. Concejo, Dym, przeł. B. Haniec, Toruń 2011, [b.n.s.]. Choć Jędrzej Wijas widzi w nich „czarne kruki o zimnym spojrzeniu”, ilustracja Concejo wydaje się otwarta na interpretacje - idem, Mała opowieść o wielkiej historii. Refleksje na marginesie książki „Dym” Antóna Fortesa i Joanny Concejo, [w:] Dziecko i baśnie świata w kontekście wczesnej edukacji, red. U. Chęcińska, Szczecin 2016, s. 254.

21 P. Grimal, Harpie, [hasło w:] idem, Słownik mitologii greckiej i rzymskiej, red. J. Łanowski, przeł. M. Bronarska et al., Wrocław 2008, s. 119.

22 D. Combrzyńska-Nogala, Bezsenność Jutki, Łódź 2012, s. 49. Bałuty to jedna z dzielnic Łodzi.

23 Ibidem, s. 66.

24 M. Szczygielski, Arka czasu, czyli wielka ucieczka Rafała od kiedyś przez wtedy do teraz i wstecz, Warszawa 2013, s. 35-36. 
chłopca sprawiły, że postrzegana przez niego rzeczywistość to świat zdominowany przez strasznych czarnych „Morloków”, którzy „pożerają” jasnych „Elojów”- jak zauważa Rafał, „widocznie taka jest natura Morloków, muszą zabijać”25.

W literaturze dziecięcej pojawia się również postać Frankensteina (nie jego potwora!). W Ostatnim przedstawieniu panny Esterki, książce obrazkowej Adama Jaromira z ilustracjami Gabrieli Cichowskiej, jeden z wychowanków Korczakowskiego Domu Sierot wspomina spotkanie z tą postacią:

— Opowiedz tę o Frankensteinie — prosi Chaim.

— Dobra... [...] Wtedy jeszcze mieszkaliśmy na Lesznie. [...] Mur jest tam z jednej strony z kamienia, a z drugiej z desek. W jednym miejscu... szpara. Wciskałem w nią nogę $\mathrm{i}-$ siup! — na drugą stronę. [...] Potem biegłem na rynek, kupowałem kilka bochenków chleba, biegłem z powrotem i przerzucałem je na drugą stronę. [...] Lecz raz zostałem przyłapany. Złapał mnie Frankenstein. Zbił i zabrał cały towar ${ }^{26}$.

Podobnie dosadny opis działalności „Frankensteina”, „tego potwora z książek”27, można odnaleźć w powieści Adama Michejdy Skarb getta z serii „Pilny na Tropie”, w której strażnik nazywany jest „diabelskim okrutnikiem”28. Przy tej okazji warto odwołać się do literatury dokumentu osobistego tworzonej przez Żydów zmuszonych do przeniesienia się w obręb granic warszawskiego getta, postać Frankensteina jest bowiem związana z tym miejscem ${ }^{29}$. Jak czy tamy w zapisach Racheli Auerbach:

Mianem [Frankensteina - K.R.] ochrzcili pewnego żandarma policjanci żydowscy, a w ślad za nimi przyjęli je [...] interesanci wylotów, szmuglerzy żydowscy i polscy, sami nawet koledzy niemieccy. Powierzchownością i postawą gość ten w niczym nie przypomina filmowego potwora, granego [...] tak sugestywnie przez Borysa Karloffa. Jest to podobno człeczyna raczej niepozorny, niewysoki, o szczupłych plecach, wąskiej twarzy i długim nosie przy nieco tylko dziwniejszych, małych, niespokojnie biegających oczach. Ma on maleńką słabość. Lubi strzelać do tłumu ${ }^{30}$.

Tak wyrażane potworne nacechowanie niemieckich żołnierzy często występuje w zapisach świadków Zagłady — Auerbach pisze również o „bestii”, która „nie pozwala nawet umrzeć tak, jak się chce” oraz „bestii z karabinem”31; po podobne metafory sięgają Chaim Aron Kapłan (na przykład „niemiecka bestia”, „ok-

25 Ibidem, s. 203. Warto dodać, że niezwykłej siły postrzeganiu świata przez Rafała dodają ilustracje Daniela de Latoura, prezentujące przerażające, czarne sylwetki „Morloków”.

26 A. Jaromir, G. Cichowska, Ostatnie przedstawienie panny Esterki, Poznań 2014, s. 42-43.

27 A. Michejda, Pilny na tropie. Skarb getta, Warszawa 2019, s. 140.

28 Ibidem.

29 Zob. J.H. Issinger, Frankenstein w warszawskim getcie. Historia i legenda, przeł. M. Półrola, „Zagłada Żydów. Studia i Materiały” 2016, nr 12, s. 187-208.

30 R. Auerbach, Pisma z getta warszawskiego, oprac. K. Szymaniak, Warszawa 2016, s. 156157. Aktor Boris Karloff znany jest z serii filmów, w których wcielił się w postać potwora Frankensteina: Frankenstein (1931), Narzeczona Frankensteina (znany też jako Powrót Frankensteina, 1935) i Syn Frankensteina (1939).

31 Ibidem, s. 210-211.

Literatura i Kultura Popularna XXVII, Wrocław 2021

(C) for this edition by CNS 
rutny drapieżnik”32) oraz Abraham Lewin (między innymi „hitlerowska bestia”, „niemiecka nazistowska blond bestia” i ,nazistowski potwór”33).

Podobnie jak świadkowie i ofiary Zagłady autorzy prozy dziecięcej nie szczędzą określeń odczłowieczających Niemców. Powielenie form występujących w literaturze dokumentu osobistego można uznać za — zapewne nieświadomy zabieg zbliżający współczesne utwory literackie i świadectwa ofiar, nie tylko osadzający teksty przeznaczone dla młodego odbiorcy w realiach historycznych, ale też odzwierciedlający nastroje ofiar Zagłady. Warto zastanowić się więc nad ideologicznym znaczeniem wykorzystania potworów w prozie historycznej, która kształtuje światopogląd projektowanego niedorosłego czytelnika. Odczłowieczenie niemieckich żołnierzy można wpisać w nurt stereotypizacji grup narodowościowych, o czym w kontekście literatury dziecięcej pisały Gertruda Skotnicka i Joanna Papuzińska ${ }^{34}$. Taka stereotypizacja jest wciąż żywa w rodzimej twórczości, trudno bowiem natrafić na utwory prezentujące skomplikowany świat wartości i moralnej dwuznaczności, zarówno po stronie niemieckiej, jak i polskiej czy żydowskiej. Choć stereotypy narodowe obecne w kulturze dziecięcej są niezwykle ciekawym zagadnieniem, chciałbym się skupić na wykorzystaniu figury potwora w kontekście natury sprawców. Czy nie jest bowiem tak, że prezentując Niemców jako monstra, autorzy sugerują, iż Zagłada została spowodowana przez nieludzkie, wręcz fantastyczne siły?

W pracach badaczy Zagłady pojawia się sugestia, aby nie mówić o nazistowskich zbrodniarzach jako o potworach, byli oni raczej „Zwykłymi” ludźmi, w „każdym z nas” istnieje bowiem pierwiastek zła, który może doprowadzić do ludobójstwa. Problem ten stał się głównym tematem rozprawy Arendt zatytułowanej Eichmann w Jerozolimie. Rzecz o banalności zła (Eichmann in Jerusalem: A Report on the Banality of Evil, 1963; wyd. pol. 1987). We wstępnie niniejszego tekstu wskazałem, że dziecięcy protagoniści odwołują się do pokładów wyobraźni, która pomaga w oswojeniu tego, co dzieje się wokół nich. Podobnie czynili dorośli, dla których Zagłada była trudna do pojęcia, w związku z czym jej sprawcy zostali pozbawieni cech ludzkich — taki obraz wyłania się z relacji filozofki, poświęconej procesowi Adolfa Eichmanna, jednego z nazistowskich zbrodniarzy, którzy zostali osądzeni i skazani. Jak jednak dowodzi autorka, u podłoża Zagłady legła „ba-

32 C.A. Kapłan, Dziennik 1939. Megila życia, przeł. i oprac. B. Górecka, Warszawa 2019, s. 65, 84. W innym miejscu Kapłan pisze, że „bestialstwo w stosunku do Żydów to narodowy obowiązek" Niemców - ibidem, s. 186. W relacji autora nie brakuje jednak przeciwnych, z pozoru realistycznych (ironicznych?), opisów okupanta: „Niemcy, którzy wkroczyli do miasta [Warszawy - K.R.], zadziwiają twarzami tryskającymi zdrowiem, świetnym umundurowaniem, rysami pełnymi godności i piękna" - ibidem, s. 121.

33 A. Lewin, Dziennik, oprac. K. Person, Warszawa 2016, s. 96, 270, 137, 149.

34 Zob. G. Skotnicka, Barwy przeszłości. O powieściach historycznych dla dzieci i młodzieży 1939-1989, Gdańsk 2008, s. 53-57; J. Papuzińska, „,My i oni”, czyli stereotypy narodowe w polskiej literaturze dziecięcej, [w:] eadem, Dziecko w świecie emocji literackich, Warszawa 1996, s. $102-105$. 
nalność zła", a nie nieludzkie usposobienie jej sprawców. Rekonstrukcja procesu i towarzyszących mu wydarzeń jasno wskazuje na stosunek opinii publicznej do Eichmanna: jest on nazywany „potworem” o „nienasyconej żądzy krwi” ${ }^{35}$. Choć to emocjonalne porównanie może być zrozumiałe, zwłaszcza w kontekście działalności nie tylko Eichmanna, ale i całej maszynerii Zagłady, Arendt przytacza również wyniki badań psychiatrów, którzy uznali go za „normalnego"36 , i demaskuje „potworność” zarzucaną mu przez niektórych komentatorów ${ }^{37}$, odrzuconą natomiast przez sędziów i samego oskarżonego ${ }^{38}$. Badaczka konkluduje:

kłopot z Eichmannem polegał na tym, że ludzi takich jak on było bardzo wielu, a nie byli oni sadystami ani osobnikami perwersyjnymi, byli natomiast — i wciąż są — okropnie i przerażająco normalni ${ }^{39}$.

W miejscu „przerażająco normalnych” niemieckich żołnierzy w polskiej literaturze pojawiają się jednak potworni naziści, należy więc stwierdzić, że zdaniem twórców na taką banalność zła najwyraźniej nie są gotowi młodzi odbiorcy. Wydaje się, że autorzy nakładają antagonistom maski potworności, by wykluczyć zbrodniarzy ze wspólnoty, pozostawić ich na marginesie kultury i cywilizacji, a tym samym zlokalizować przyczyny Zagłady poza ludzkim rozumem i aksjologią. W dominacji tego rodzaju konwencji widzę jednak zagrożenie, może to bowiem prowadzić do fałszywego pocieszenia, że Zagłada lub inne, równie dramatyczne wydarzenie, już się nie powtórzy, gdyż jej sprawcy wpisywani są w sferę fantastyki, a sam przebieg wydarzeń nabiera cech niesamowitości. Tego rodzaju strategia może ponadto wpłynąć na projektowanego czytelnika dziecięcego, który w każdym przeciwniku będzie mógł dostrzec wyłącznie potwora, a nie drugiego człowieka.

\section{Bibliografia}

\section{Teksty}

Auerbach R., Pisma z getta warszawskiego, oprac. K. Szymaniak, ŻIH, Warszawa 2016.

Bart A., Fabryka muchołapek, W.A.B., Warszawa 2008.

Bąkiewicz G., Ale historia... Ta potworna wojna, Nasza Księgarnia, Warszawa 2019.

Beręsewicz P., Czy wojna jest dla dziewczyn?, Literatura, Łódź 2010.

Cali D., Bloch S., Wróg, przeł. K. Skalska, Zakamarki, Poznań 2014.

Combrzyńska-Nogala D., Bezsenność Jutki, Literatura, Łódź 2012.

Czerwińska-Rydel A., Listy w butelce. Opowieść o Irenie Sendlerowej, Literatura, Łódź 2018.

Dukaj J., Wroniec, Wydawnictwo Literackie, Kraków 2009.

\footnotetext{
35 Zob. H. Arendt, op. cit., s. 14, 321.

36 Zob. ibidem, s. 36.

37 Zob. ibidem, s. 72.

38 Zob. ibidem, s. 319, 358.

39 Ibidem, s. 359.
} 
Fabicka J., Rutka, Agora SA, Warszawa 2016.

Fortes A., Concejo J., Dym, przeł. B. Haniec, Tako, Toruń 2011.

Jaromir A., Cichowska G., Ostatnie przedstawienie panny Esterki, Media Rodzina, Poznań 2014.

Kapłan C.A., Dziennik 1939. Megila życia, przeł. i oprac. B. Górecka, ŻIH, Warszawa 2019.

Kulka O.D., Pejzaże metropolii śmierci. Rozmyślania o pamięci i wyobraźni, przeł. M. Szczubiałka, Czarne, Wołowiec 2014.

Lewin A., Dziennik, oprac. K. Person, ŻIH, Warszawa 2016.

Michejda A., Skarb getta, Oficyna 4em, Warszawa 2019.

Ostrowicka B., Jest taka historia. Opowieść o Januszu Korczaku, Literatura, Łódź 2012.

Papuzińska J., Asiunia, Literatura, Łódź 2011.

Papuzińska J., Krasnale i olbrzymy, Literatura, Łódź 2015.

Papuzińska J., Mój tato szczęściarz, Literatura, Łódź 2014.

Rudniańska J., Kotka Brygidy, Pierwsze, Lasek 2007.

Rudnicki A., Kupiec łódzki, [w:] idem, Kupiec łódzki. Niebieskie kartki, PIW, Warszawa 1963, s. $8-51$.

Szczygielski M., Arka czasu, czyli wielka ucieczka Rafała od kiedyś przez wtedy do teraz $i$ wstecz, Wydawnictwo Piotra Marciszuka STENTOR, Warszawa 2013.

Sierakowiak D., Dziennik, oprac. E. Wiatr, A. Sitarek, ŻIH, Warszawa 2016.

Terranova N., Amit O., Bruno. Chłopiec, który nauczyt się latać, przeł. J. Wajs, Format, Wrocław 2016.

\section{Opracowania}

Arendt H., Eichmann w Jerozolimie. Rzecz o banalności zła, przeł. A. Szostkiewicz, Znak, Kraków 2010.

Grimal P., Harpie, [hasło w:] idem, Słownik mitologii greckiej i rzymskiej, red. J. Łanowski, przeł. M. Bronarska et al., Wrocław 2008, s. 119.

Issinger J.H., Frankenstein w warszawskim getcie. Historia i legenda, przeł. M. Półrola, „Zagłada Żydów. Studia i Materiały” 2016, nr 12, s. 187-208.

Kokkola L., Representing the Holocaust in Children's Literature, Routledge, London 2003.

Papuzińska J., Dziecko w świecie emocji literackich, Wydawnictwo SBP, Warszawa 1996.

Pekaniec A., Dwie opowieści o wojnie, Holokauście i nie tylko. Kotka Brygidy Joanny Rudniańskiej i Rutka Joanny Fabickiej, „Czy/tam/czy/tu. Literatura dziecięca i jej konteksty” 2017, nr 1, s. 8-29.

Rybak K., Dzieciństwo w labiryncie getta. Recepcja mitu labiryntu w polskiej literaturze dziecięcej o Zagtadzie, WUW, Warszawa 2019.

Rybak K., Oczami dziecka, https://bit.ly/2VZ0MEf (dostęp: 27.12.2019).

Rybak K., Żyd i uchodźca. Znaczace powinowactwa narracyjne w polskiej literaturze dziecięcej ostatniej dekady, „Czy/tam/czy/tu. Literatura dziecięca i jej konteksty” 2017, nr 2, s. 44-62.

Skotnicka G., Barwy przeszłości. O powieściach historycznych dla dzieci i młodzieży 1939-1989, słowo/obraz terytoria, Gdańsk 2008.

Skowera M., Rutka, [hasło w:] Our Mythical Childhood Survey, https://bit.ly/3ioCNFR (dostęp: 27.12.2019).

Slany K., Rutka Joanny Fabickiej jako przykład postpamięciowej literatury dla dzieci, „Maska” 2017, nr 35, s. 81-94.

Wądolny-Tatar K., Synekdocha jako trop wizualny w książkowych ilustracjach dla dzieci (na przykładzie wybranych narracji stowa i obrazu o drugiej wojnie światowej), [w:] Literatura i inne sztuki w przestrzeni edukacyjnej dziecka, red. A. Ungeheuer-Gołąb, U. Kopeć, Wydawnictwo Uniwersytetu Rzeszowskiego, Rzeszów 2016, s. 164-176. 
Wijas J., Mała opowieść o wielkiej historii. Refleksje na marginesie książki „Dym” Antóna Fortesa i Joanny Concejo, [w:] Dziecko i baśnie świata w kontekśsie wczesnej edukacji, red. U. Chęcińska, Wydawnictwo Naukowe Uniwersytetu Szczecińskiego, Szczecin 2016, s. 249-260. Wróblewska V., „Od potworów do znaków pustych”. Ludowe demony w polskiej literaturze dla dzieci, Wydawnictwo Naukowe Uniwersytetu Mikołaja Kopernika, Toruń 2014.

\title{
Minotaur, Morlock, a Beast... Images of German Soldiers in Polish Children's Literature about the Holocaust
}

\begin{abstract}
Summary
The aim of the article is to create a 'bestiary' of monstrous German soldiers appearing in Polish Holocaust children's literature of the 21st century. Body of analyzed works consists of Rutka by Joanna Fabicka, Bezsenność Jutki by Dorota Combrzyńska-Nogala, and Arka czasu by Marcin Szczygielski, among others. The figures of monstrosity were divided into three groups, as the characters (1) preserve the natural appearance of a man, or exceed the physical norm as being (2) the result of the author's imagination or (3) references to other cultural texts. The negative and inhuman way of depicting the antagonists raises a certain doubt, caused by the reading of Eichmann in Jerusalem: A Report on the Banality of Evil by Hannah Arendt - the final part of the article is devoted to the problem expressed in the subtitle of her work.
\end{abstract}

